\title{
The wzm gene located on the pRhico plasmid of Azospirillum brasilense Sp7 is involved in lipopolysaccharide synthesis
}

Correspondence

Saul Burdman

saulb@agri.huji.ac.il

Received 30 June 2008

Revised 11 November 2008

Accepted 14 November 2008
Anat Lerner, Yaacov Okon and Saul Burdman

Department of Plant Pathology and Microbiology and The Otto Warburg Center for Agricultural Biotechnology, The Robert H. Smith Faculty of Agriculture, Food and Environment, The Hebrew University of Jerusalem, Rehovot 76100, Israel

Several genes involved in the interaction between Azospirillum brasilense Sp7 and plants are located on the pRhico plasmid. Here we report the characterization of an Sp7 mutant strain with impairment of the pRhico-located gene wzm. This gene encodes an inner-membrane component of an ATP-binding cassette (ABC) transporter with similarity to transporters involved in surface polysaccharide export. Indeed, SDS-PAGE revealed that LPS synthesis is affected in the wzm mutant. No significant differences were observed between wild-type and mutant strains in exopolysaccharide (EPS) amount; however, several differences were observed between them in EPS monosaccharide composition, and only wild-type colonies stained positively with Congo red. Microscopy revealed that wzm mutant cells are longer and thinner, and exhibit several differences in their cell surface relative to the wild-type. The wzm mutant was more resistant to oxidative stress, starvation, desiccation, heat and osmotic shock than the wild-type. In contrast, the mutant was more susceptible than the wild-type to UV radiation and saline stress. The strains also differed in their susceptibility to different antibiotics. Differences between the strains were also observed in their outer-membrane protein composition. No differences were observed between strains in their ability to attach to sweet corn roots and seeds, and to promote growth under the tested conditions. As LPS plays an important role in cell envelope structural integrity, we propose that the pleiotropic phenotypic changes observed in the wzm mutant are due to its altered LPS relative to the wild-type.

\section{INTRODUCTION}

The Azospirillum genus belongs to the alpha-proteobacteria and comprises free-living, nitrogen-fixing, vibrio- or spirillum-shaped rods that exert beneficial effects on plant growth and yield of many crops of agronomic importance (Dobbelaere et al., 2001). Plant growth promotion by Azospirillum is attributed to morphological and physiological changes in inoculated plant roots, which enhance water and mineral uptake. Plant growth substances, such as auxins, cytokinins and gibberellins (Steenhoudt \& Vanderleyden, 2000; Dobbelaere et al., 2001), as well as nitric oxide (Creus et al., 2005) produced by the bacteria are at least partially responsible for the plant growth promotion.

\footnotetext{
Abbreviations: ABC, ATP-binding cassette; CPS, capsular polysaccharide; d.a.s., days after sowing; DOC, deoxycholic acid; EPS, exopolysaccharide; OM, outer membrane; OMP, outer-membrane protein; SEM, scanning electron microscopy.

A supplementary table listing bacterial strains and plasmids used in this study, with supplementary references, is available with the online version of this paper.
}

Within the Azospirillum genus, one of the most studied species is Azospirillum brasilense (Tarrand et al., 1978). A. brasilense cells are surrounded by a dense, tightly cellbound layer of capsular polysaccharides (CPSs), and by outer exopolysaccharides (EPSs), which are loosely bound to the cell and easily detached by centrifugation (Burdman et al., 2000c). EPSs and CPSs, as well as extracellular proteins, have been shown to play important roles in bacterial aggregation and in the establishment of the bacterium-plant association (Burdman et al., 1999, 2000c; Steenhoudt \& Vanderleyden, 2000). It has been suggested that EPSs and CPSs are involved in anchoring the bacteria to the surface of wheat roots (Michiels et al., 1991), and in the proliferation of azospirilla in the root (Katupitiya et al., 1995).

In media characterized by a low carbon-to-nitrogen $(\mathrm{C}: \mathrm{N})$ ratio, A. brasilense cells tend to grow in a dispersive form, whereas in a high $\mathrm{C}: \mathrm{N}$ medium, the cells tend to aggregate and flocculate (del Gallo et al., 1989; Burdman et al., 2000b). Cell aggregation in A. brasilense has been shown to correlate positively with the amount of EPS produced (Burdman et al., 2000b). Moreover, EPS mutants of $A$. 
brasilense that have lost the ability to bind calcofluor are not able to aggregate and anchor to wheat roots, thus supporting the involvement of extracellular $\beta$ 1-3 and/or $\beta$ 1-4 polysaccharides in aggregation and root attachment (del Gallo et al., 1989; de Troch, 1993). Several studies have been performed on A. brasilense LPS, and a few LPSdefective mutants are available (Katzy et al., 1998). However, little is known about the involvement of LPS in the interaction of $A$. brasilense with plant roots, or about the role played by LPS in the response of the bacterium to the environment.

A. brasilense strains carry large plasmids (Holguin et al., 1999). For instance, A. brasilense Sp7 contains five large plasmids, three with molecular masses of 46, 90 and $115 \mathrm{MDa}$, and two with molecular masses greater than $300 \mathrm{MDa}$ (Vanstockem et al., 1987). The $90 \mathrm{MDa}$ plasmid, termed pRhico or p90, is widespread among A. brasilense strains, and contains genes involved in their interaction with plant roots, synthesis of surface polysaccharides, motility and growth on minimal medium (Croes et al., 1991; Vanbleu et al., 2004). Recent release of the Sp7 pRhico sequence (Vanbleu et al., 2004) has revealed that this plasmid contains two genes, wzm (pRhico062) and wzt (pRhico064), which encode components of transport systems belonging to the ATP-binding cassette (ABC) superfamily. $\mathrm{ABC}$ transport systems are composed of a hydrophobic integral membrane protein, which spans the membrane multiple times in an alpha-helical conformation, and a hydrophilic, membrane-associated ATP-binding protein, which is exposed to the cytoplasm (Davidson, 2002).

In Gram-negative bacteria, extracellular polysaccharides such as LPS, CPS and EPS are exported across the two membranes via $\mathrm{ABC}$ transporters (Schneider \& Hunke, 1998; Silver et al., 2001). Sequence analysis of the Sp7 wzm and wzt products suggests that they could be involved in translocation of extracellular polysaccharides. To deepen our understanding of the biosynthesis of extracellular polysaccharides in A. brasilense Sp7 and of their role in the plant-bacterium association, we generated a $w z m$ knockout mutant. Here we report the characterization of this mutant, which was assessed for its LPS pattern, EPS composition, response to several stresses and morphological properties. We show that the wzm mutation affects LPS synthesis and is responsible for many pleiotropic phenotypic changes in strain Sp7.

\section{METHODS}

Bacterial strains, plasmids and media. The strains and plasmids used in this study are listed in Supplementary Table S1. For shortterm maintenance and preparation of starter cultures, $A$. brasilense strains were grown at $30{ }^{\circ} \mathrm{C}$ in Luria-Bertani medium (LB; Difco). Experiments were performed in high $\mathrm{C}: \mathrm{N}$ ratio medium, with $37 \mathrm{mM}$ fructose as the carbon source (Burdman et al., 1999) unless otherwise stated. LB was used to cultivate Escherichia coli strains at $37{ }^{\circ} \mathrm{C}$. Triparental mating was performed on D-plates (8 g Bacto nutrient broth $\mathrm{l}^{-1}, 0.25 \mathrm{~g} \mathrm{MgSO}_{4} \cdot 7 \mathrm{H}_{2} \mathrm{O} \mathrm{l}^{-1}, 1.0 \mathrm{~g} \mathrm{KCl}^{-1}, 0.01 \mathrm{~g}$ $\mathrm{MnCl}_{2}, 2 \%$ agar) and A. brasilense transconjugants were selected on minimal medium for A. brasilense (MMAB) as described by Vanstockem et al. (1987), supplemented with kanamycin (Km; $25 \mu \mathrm{g} \mathrm{ml}^{-1}$ ) and trimethoprim (Tr; $25 \mu \mathrm{g} \mathrm{ml}^{-1}$ ).

DNA manipulations and sequence analyses. Cloning and transformation procedures were performed according to standard methods (Sambrook et al., 1989). Total DNA was isolated using the Wizard Genomic DNA Purification kit (Promega). For Southern blotting, DNA was digested with restriction enzymes purchased from New England BioLabs, electrophoresed, and blotted onto MSI nylon transfer membranes (Roche Diagnostics) by standard methods (Sambrook et al., 1989). Detection was performed using the DIG DNA Labeling kit (Roche Diagnostics). PCR amplifications were performed on an automated Eppendorf Mastercycler. Sequence analyses were performed using the BLAST network service (Altschul et al., 1997) and Pfam (http://pfam.sanger.ac.uk/). Oligonucleotide primers were synthesized using the Primer3 program (http:// www.es.embnet.org/cgi-bin/primer3_www.cgi) and purchased from Hy Laboratories. A hydropathy plot of the wzm product was obtained by the method of Kyte \& Doolittle (1982).

Construction of an A. brasilense Sp7 wzm ::Km mutant. A 734 bp internal fragment of the $w z m$ (pRhico062) coding region was PCR-amplified using primers $a b c T$-L (5'-GAGATCGAAGCCCGATAC- $\left.3^{\prime}\right)$ and $a b c T-R\left(5^{\prime}\right.$-ATGTCGGCAAATCCAGTA-3'). These primers were designed based on the pRhico sequence (Vanbleu et al., 2004). The PCR mixtures $(25 \mu \mathrm{l})$ contained $0.3 \mu \mathrm{l} \mathrm{Taq}$ polymerase (Promega), $2.5 \mu \mathrm{l} 10 \times$ buffer (Promega), $3.75 \mathrm{mM} \mathrm{MgCl} 2,0.8 \mu \mathrm{M}$ of each primer, $0.2 \mathrm{mM}$ of each dNTP (Promega), $0.4 \mathrm{mg} \mathrm{BSA} \mathrm{ml}^{-1}$ (Sigma), and $1 \mu \mathrm{l}$ template DNA. Amplifications were performed with an initial denaturation cycle of $3 \mathrm{~min}$ at $95{ }^{\circ} \mathrm{C}$, followed by 35 cycles of denaturation for $30 \mathrm{~s}$ at $94^{\circ} \mathrm{C}$, annealing for $30 \mathrm{~s}$ at $58.5^{\circ} \mathrm{C}$, and elongation for $45 \mathrm{~s}$ at $72{ }^{\circ} \mathrm{C}$. A final extension step was performed at $72{ }^{\circ} \mathrm{C}$ for $5 \mathrm{~min}$. The PCR product was purified and cloned into pGEM-T Easy Vector (Promega) to generate plasmid $\mathrm{pABC}$, which was transformed into E. coli DH5 $\alpha$. Following sequencing to confirm the identity of the cloned fragment, the $1.2 \mathrm{~kb}$ HincII Km-resistance cassette from pUCA800 was inserted into the unique EcoNI site of $w z m$ (Fig. 1) in pABC to yield pABC-Km. Then, the $2 \mathrm{~kb} w z m:: \mathrm{Km}$ fragment from pABC-Km was excised from this plasmid using SalI and SphI, and cloned into the suicide vector pSUP202 that was pretreated with the same enzymes, to give pSUP$\mathrm{ABC}-\mathrm{Km}$. This vector was subsequently transformed into E. coli S17.1, which was further used to mobilize it to A. brasilense Sp7 through triparental mating, using E. coli HB101 carrying the helper vector pRK2073 (Vanstockem et al., 1987). A. brasilense transconjugants were selected on MMAB supplemented with $\mathrm{Km}$ and $\mathrm{Tr}$, and $\mathrm{Km}$ resistant clones were verified by Southern blotting and PCR. One of the confirmed $w z m:: \mathrm{Km}$ mutants (hereafter, wzm mutant) was selected for further analysis.

Extraction of LPS. LPSs were extracted from wild-type and wzm mutant cells grown in LB and in high $\mathrm{C}: \mathrm{N}$ medium, using published procedures (Cava et al., 1989; Brink et al., 1990; Tao et al., 1992). Briefly, $1 \mathrm{ml}$ of overnight-grown cultures were centrifuged $(13000 \mathrm{~g}$, $1 \mathrm{~min}$, twice), and the resulting pellets were resuspended in $130 \mu \mathrm{l}$ SDS sample buffer. The samples were then boiled for $5 \mathrm{~min}$ at $100{ }^{\circ} \mathrm{C}$, and following removal of cell debris, proteinase $\mathrm{K}$ was added to a final concentration of $0.5 \mu \mathrm{g} \mu \mathrm{l}^{-1}$. The samples were incubated at $37^{\circ} \mathrm{C}$ for $1 \mathrm{~h}$; afterwards, $20 \mu \mathrm{l}$ aliquots were loaded onto SDS-PAGE gels containing 3 and $15 \%$ polyacrylamide concentrations in the stacking and resolving gels, respectively. The samples were electrophoresed at $15 \mathrm{~mA}$ for $3.5 \mathrm{~h}$, and following electroblotting $(70 \mathrm{~V}, 1 \mathrm{~h})$ to a nylon membrane (Rosch) to remove residual proteins, the gels were silverstained according to Tsai \& Frasch (1982). In other experiments, LPSs 


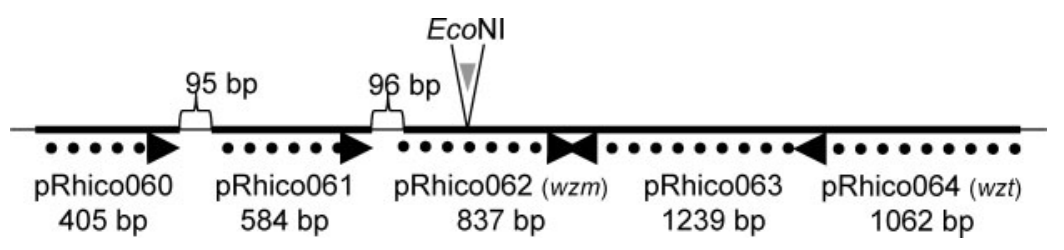

Fig. 1. Location of the wzm gene (pRhico062) in the pRhico plasmid of Azospirillum brasilense Sp7 (Vanbleu et al., 2004). Insertion of the $\mathrm{Km}$ cassette in the EcoNI site for generation of the knockout strain is indicated. were extracted with an LPS extraction kit (Intron Biotechnology), and samples were run on a deoxycholic acid (DOC)-polyacrylamide gel according to Reuhs et al. (1998).

Extraction of EPS. A $6 \mathrm{ml}$ aliquot of overnight cultures of $A$. brasilense $\mathrm{Sp} 7$ or $w z m$ mutant in high $\mathrm{C}: \mathrm{N}$ medium at $6 \times 10^{8}$ c.f.u. $\mathrm{ml}^{-1}$ was used to inoculate 11 of high $\mathrm{C}: \mathrm{N}$ medium. After $48 \mathrm{~h}$ of growth at $30{ }^{\circ} \mathrm{C}$ with agitation at 250 r.p.m., when the cultures reached $\mathrm{OD}_{600} 0.8-0.9$, EPSs were extracted as described by Burdman et al. (2000b). Sugar amount was evaluated by the anthrone method (Dische, 1962). Microbial mass was determined by measuring the dry cell mass of pelleted cells at $80{ }^{\circ} \mathrm{C}$ until a constant weight was reached. Identification of EPS monosaccharide composition was performed at the Center for Glycobiology at Ben-Gurion University of the Negev (Beer-Sheva, Israel) according to Albersheim et al. (1967), with minor modifications. Sugar composition of modified alditols was determined in a Hewlett Packard HP 5890 Series II gas chromatograph, equipped with a DB-225 capillary column $(30 \mathrm{~m} \times 0.25 \mathrm{~mm})$ from J\&W Scientific and a flame-ionization detector (FID) at $250{ }^{\circ} \mathrm{C}$. Samples $(1 \mu \mathrm{l})$ of mixed alditols were separated at $220{ }^{\circ} \mathrm{C}$ with helium as the carrier gas. These experiments were conducted twice.

Congo red and calcofluor staining. Congo red and calcofluor staining was performed twice for each strain, as described by Rodríguez Cáceres (1982) and Croes et al. (1991), respectively.

Microscopy. For observation of viable bacterial cells and qualitative evaluation of cell motility, bacteria were grown for $24 \mathrm{~h}$ in high $\mathrm{C}: \mathrm{N}$ medium, and cells were visualized in an Olympus BX 51 phase contrast microscope with an Olympus SC 35 type 12 camera. For scanning electron microscopy (SEM), cells were grown as described above and $500 \mu \mathrm{l}$ of culture (at $10^{7}$ c.f.u. $\mathrm{ml}^{-1}$ ) was collected. Cells were centrifuged $\left(4500 \mathrm{~g}, 10 \mathrm{~min}, 20^{\circ} \mathrm{C}\right)$ and washed twice with $100 \mathrm{mM}$ phosphate buffer ( $\mathrm{pH}$ 6.8). The pellets were resuspended in fixation solution (2\% glutaraldehyde, $3 \%$ paraformaldehyde, $0.1 \mathrm{M}$ cacodylate buffer) and gently shaken for $1 \mathrm{~h}$ at room temperature. Following centrifugation $\left(3620 \mathrm{~g}, 10 \mathrm{~min}, 20^{\circ} \mathrm{C}\right), 0.1 \mathrm{M}$ cacodylate buffer was added to the pellets. The cells were attached to silica chips coated with polylysine and kept overnight in a humid atmosphere. The samples were exposed to an additional fixation treatment with $1 \% \mathrm{OsO}_{4}$ in $0.1 \mathrm{M}$ cacodylate buffer for $1 \mathrm{~h}$, and then washed twice in $0.1 \mathrm{M}$ cacodylate buffer with gentle shaking for $5 \mathrm{~min}$, and twice with $0.5 \mathrm{ml}$ double-distilled water (DDW). Tannic acid (1\%) was added to the tubes, which were kept for $5 \mathrm{~min}$ in the dark. After two washes with DDW, $1 \%$ uranyl acetate was added and the samples were shaken for $30 \mathrm{~min}$ in the dark. Dehydration was performed after two washes in DDW, by graded ethanol series and final drying in a critical point dryer (CPD 030, Bal-Tec). Dried bacteria were coated with gold in an Edwards S150 sputter coater and the samples were observed by SEM (Carl Zeiss, SUPRA 55VP).

Growth curves. Wild-type and mutant strains were grown overnight in $5 \mathrm{ml} \mathrm{LB}$ supplemented with antibiotics $\mathrm{Tr}$ and $\mathrm{Km}+\mathrm{Tr}$, respectively. Then, $30 \mu \mathrm{l}$ of the cell suspensions (at about $6 \times 10^{8}$ c.f.u. $\mathrm{ml}^{-1}$ ) were transferred to $100 \mathrm{ml}$ Erlenmeyer flasks containing $30 \mathrm{ml}$ high $\mathrm{C}: \mathrm{N}$ medium with different carbon sources (D-fructose,
DL-malic acid, D-mannose, D-glucose, D-galactose, L-rhamnose, Darabinose, L-arabinose and D-xylose) at $37 \mathrm{mM}$. Cultures were grown at $30{ }^{\circ} \mathrm{C}$ with agitation at 200 r.p.m., and the $\mathrm{OD}_{600}$ was measured every 2-3 h over the course of $48 \mathrm{~h}$ using a spectrophotometer (Coleman Junior II 6/20, Perkin-Elmer). The experiments were conducted twice, and in each experiment, the different media (with the different carbon sources) were inoculated with aliquots from the same pre-culture.

Starvation experiments. Aliquots $(10 \mathrm{ml})$ of overnight, high $\mathrm{C}: \mathrm{N}$ medium cultures of wild-type and mutant strains at approximately $6 \times 10^{8}$ c.f.u. $\mathrm{ml}^{-1}$ were washed twice by centrifugation $(4000 \mathrm{~g}$, $10 \mathrm{~min}$ ). Cells were resuspended in $0.06 \mathrm{M}$ potassium phosphate buffer ( $\mathrm{pH}$ 6.8) and incubated on a shaker at 200 r.p.m., $30{ }^{\circ} \mathrm{C}$ for 12 days under starvation, as described by Kadouri et al. (2002). Bacterial viability was determined by dilution plating at the beginning and end of the incubation period. This experiment was repeated three times.

Stress endurance. In all experiments, $0.5 \mathrm{ml}$ aliquots of LB-grown overnight cultures of wild-type and mutant strains were used to inoculate $100 \mathrm{ml}$ Erlenmeyer flasks containing $30 \mathrm{ml}$ high C:N medium, and grown for $24 \mathrm{~h}$ at $30{ }^{\circ} \mathrm{C}$ with agitation at 250 r.p.m. The resulting cultures were used to assess bacterial survival under various stresses. The percentage of viable cells was determined following dilution plating at the beginning and end of each experiment, and/or during the course of the experiment. In all experiments, the initial number of cells was $5 \times 10^{8}-7 \times 10^{8}$ c.f.u. $\mathrm{ml}^{-1}$. All experiments were conducted three times as described by Kadouri et al. (2003) with the following modifications: in the heatresistance experiments, $10 \mathrm{ml}$ of culture was incubated in a water bath at $55{ }^{\circ} \mathrm{C}$ for $60 \mathrm{~min}$. Bacterial viability was determined every $15 \mathrm{~min}$. In experiments performed to assess resistance to UV radiation, cells were exposed to UV radiation for $120 \mathrm{~s}$, and bacterial viability was determined every $30 \mathrm{~s}$. To assess survival of cells following desiccation, $1 \mathrm{ml}$ cultures were washed twice by centrifugation with sterile DDW. Pelleted cells were resuspended in $100 \mu \mathrm{l}$ DDW and transferred to $0.2 \mu \mathrm{m}$ pore-size membrane filter papers (Whatman). The membranes were air-dried as described by Kadouri et al. (2003), transferred to $50 \mathrm{ml}$ flasks and resuspended in $1 \mathrm{ml} 0.06 \mathrm{M}$ potassium phosphate buffer ( $\mathrm{pH}$ 6.8). The flasks were shaken overnight at room temperature and cell viability was determined as described above. Sensitivity to osmotic pressure was determined by adding one volume of 2 or $4 \mathrm{M}$ fructose to the cultures, yielding final fructose concentrations of 1 and $2 \mathrm{M}$, respectively. The suspensions were incubated at $30{ }^{\circ} \mathrm{C}$ for $24 \mathrm{~h}$.

Sensitivity to hydrogen peroxide, antibiotics and SDS. Sensitivity to hydrogen peroxide and several antibiotics was measured as described by Kadouri et al. (2003). To assess the sensitivity of the strains to SDS, cells were grown in high $\mathrm{C}: \mathrm{N}$ medium supplemented with $0.01 \%$ SDS. All experiments were performed three times.

Sensitivity to saline stress. Wild-type and wzm mutant strains were grown overnight in $5 \mathrm{ml}$ LB supplemented with $\mathrm{Tr}$ and $\mathrm{Km}+\mathrm{Tr}$, respectively. Aliquots $\left(30 \mu \mathrm{l}\right.$ ) of cultures (at $\sim 6 \times 10^{8}$ c.f.u. $\mathrm{ml}^{-1}$ ) were 
transferred to $100 \mathrm{ml}$ Erlenmeyer flasks containing $30 \mathrm{ml}$ high C:N medium with 300,400 or $500 \mathrm{mM} \mathrm{NaCl}$. Cultures were grown for $48 \mathrm{~h}$ at $30{ }^{\circ} \mathrm{C}$ with shaking (200 r.p.m.), and their $\mathrm{OD}_{600}$ was measured every $2-3 \mathrm{~h}$. The experiment was conducted twice.

Extraction of outer-membrane proteins (OMPs). OMP fractions were obtained as described by Burdman et al. (1998), from wild-type and wzm mutant strains grown for $48 \mathrm{~h}$ in high $\mathrm{C}: \mathrm{N}$ medium. Protein concentrations were determined using the Bio-Rad protein assay reagent. Proteins were separated by SDS-PAGE (12\% acrylamide), and stained with Coomassie brilliant blue by standard methods (Laemmli, 1970).

Plant growth promotion experiments. Seeds of sweet corn (Zea mays cv. Jubilee; Neta Quality Seeds) were surface-sterilized by soaking them for $5 \mathrm{~min}$ in absolute ethanol followed by five washes with sterile distilled water (DW). They were then placed in $50 \mathrm{ml}$ Falcon tubes containing $30 \mathrm{ml}$ bacterial suspension (Sp7 or $w z m$ mutant) at $3 \times 10^{7}-6 \times 10^{7}$ c.f.u. $\mathrm{ml}^{-1}$. Controls were seeds incubated in $30 \mathrm{ml}$ sterile DW. The tubes were shaken at 200 r.p.m. for $3 \mathrm{~h}$ at room temperature. Then the seeds were collected, air-dried and sown in pots $(11.5 \times 9 \times 6 \mathrm{~cm})$ filled with autoclaved vermiculite $3 \mathrm{G}$ (Agrekal), and covered with a $1 \mathrm{~cm}$ layer of autoclaved perlite 4 (Agrekal). The pots were maintained in a greenhouse $\left(25^{\circ} \mathrm{C}, 15 \mathrm{~h}\right.$ light period), and were watered with $100 \mathrm{ml}$ sterile DW every 45 days. Four experiments were carried out. In two experiments, five seeds were sown per pot, with three pots per treatment. After germination, three plants were kept in each pot, and plants were grown up to 21 days after sowing (d.a.s.). In the other two experiments, four seeds were sown per pot, with seven pots per treatment. Only one plant per pot was kept after germination and plants were grown for up to 18 d.a.s. Tested growth parameters included root and shoot wet and dry weight, and root and shoot length.

Root adhesion assays. Sweet corn seeds ('Jubilee') were surfacesterilized, treated with wild-type and mutant strains, and sown as described above for the first two growth promotion experiments. To determine the approximate number of bacterial cells that adhered to the seeds, four seeds per treatment were randomly selected. These seeds were transferred to $15 \mathrm{ml}$ Falcon tubes containing $1 \mathrm{ml}$ sterile DW, and were shaken at 200 r.p.m. overnight at room temperature. Then $0.5 \mathrm{ml}$ of the suspensions was used for cell counting by dilution plating. To determine the approximate number of bacterial cells present on the roots, plants were removed from the pots 18 or 21 d.a.s., and the roots were cut and transferred to $50 \mathrm{ml}$ Falcon flasks containing $25 \mathrm{ml}$ sterile DW. The flasks were shaken at 200 r.p.m. overnight at room temperature. Then the suspensions were collected and used for cell counting by dilution plating. For dilution plating, solid high $\mathrm{C}$ : $\mathrm{N}$ medium containing $\mathrm{Tr}$ and cycloheximide $(\mathrm{Ch} ; 25 \mu \mathrm{g}$ $\mathrm{ml}^{-1}$ ) was used.

Statistics. Experiments were statistically analysed by one-way analysis of variance (ANOVA) using JMP software (SAS Institute), unless otherwise stated.

\section{RESULTS}

\section{Sequence analysis of the A. brasilense Sp7 wzm gene}

The Sp7 pRhico plasmid contains a cluster of genes involved in surface polysaccharide biosynthesis (Vanbleu et al., 2004). These genes can be grouped into three distinct categories based on the processes in which they are involved: (i) synthesis of nucleotide sugar precursors; (ii) transfer of activated sugars to the growing carbohydrate chain; and (iii) export, polymerization and assembly of the oligosaccharides or polysaccharides. This cluster contains two genes, wzm (pRhico062, GenBank accession no. AAS83098) and wzt (pRhico064, GenBank accession no. AAS83100) (Fig. 1), which putatively encode a 278 aa ATP transporter permease and a 353 aa ABC transporter ATPbinding component-like protein, respectively (Vanbleu et al., 2004).

In this study, we focused on wzm. Pfam analysis revealed that the predicted Wzm contains an ABC-2 membrane domain (PF01061) from amino acids 26 to 239. This domain is characteristic of a subfamily of ABC-type transport systems that catalyse export of drugs or carbohydrates, including surface polysaccharides (Reizer et al., 1992). BLASTP confirmed that the wzm product is similar to inner-membrane subunits of ABC-2-type transporters. The highest similarity among reference (refseq) proteins was a Pseudomonas fluorescens ABC-2type transporter protein (YP_262563), with $50 \%$ identity and $72 \%$ similarity for a large portion of these proteins (amino acids 22-278 of Wzm). Similar homology parameters ( $46-50 \%$ identity, and $66-70 \%$ similarity to similar portions of the predicted proteins) were found between Wzm and the inner-membrane proteins of an $\mathrm{ABC}$ polysaccharide efflux pump of Burkholderia xenovorans (YP_554653), an ABC O-antigen/LPS exporter of Xanthomonas oryzae pv. oryzicola (ZP_0224686), an ABC polysaccharide/polyol phosphate export pump of Burkholderia sp., and a putative LPS transporter of Burkholderia pseudomallei (ZP_02456953), among others. Hydropathy plot analysis of the wzm product supports a hydrophobic protein, which is predicted to span the membrane six times (data not shown), as is typical for inner-membrane components of $\mathrm{ABC}$ transporters.

\section{Generation of an A. brasilense wzm mutant and its initial characterization}

To assess whether wzm plays a role in the synthesis of LPSs and/or EPSs of $A$. brasilense, we generated a knockout strain for this gene in the background of strain $\mathrm{Sp} 7$ by marker exchange. The selected mutant was confirmed by PCR and Southern blotting (not shown). Initial observations revealed that, in contrast to the relatively smooth colonies produced by wild-type $\mathrm{Sp} 7$ after $48 \mathrm{~h}$ of growth in solid high $\mathrm{C}: \mathrm{N}$ medium, colonies of the wzm mutant have a rough appearance (results not shown). LPSs of Gramnegative bacteria generally consist of lipid A, a polysaccharide component with an inner and outer core, and the variable $\mathrm{O}$-antigen portion composed of oligosaccharide subunits. In several species, a switch from smooth to rough colonies occurs in mutants that fail to add the inner core or the O-specific chain (Godowski, 2005; Wolf \& Goldberg, 2006). Thus, the observed differences in colony morphology between the wild-type and wzm mutant support the 
involvement of $w z m$ in LPS synthesis, as inferred by sequence analysis of this gene.

The wzm mutant colonies showed an unusual orange pigmentation when grown on solid media (results not shown). Therefore, molecular assays were performed to ensure that the mutant was indeed $A$. brasilense rather than a contaminant. These tests included PCR using an $A$. brasilense 16S rDNA primer set (Herschkovitz et al., 2005) and sequencing of the obtained product, as well as denaturing gradient gel electrophoresis (DGGE) analysis using universal 16S rDNA primers (Lerner et al., 2006). Results from these tests confirmed that the mutant was indeed derived from A. brasilense Sp7 (results not shown).

\section{Analyses of LPSs and EPSs of the wzm mutant}

We then compared LPS patterns of mutant and wild-type strains, following LPS extraction from boiled cells and SDS-PAGE analysis. Clear differences in LPS profiles were found between the two strains after growth in both LB and high $\mathrm{C}: \mathrm{N}$ medium with fructose as the carbon source (Fig. 2). In both cases, the wild-type pattern showed a high and an intermediate molecular mass band absent in the wzm mutant profiles (Fig. 2, arrows 1 and 2, respectively). Similarly sized bands have been observed in other LPS studies of $A$. brasilense strains, including with strain Sp7 (Katzy et al., 1998; Konnova et al., 2008). These bands (arrows 1 and 2, respectively) have been shown to correspond to the smooth-LPS (containing lipid A, core oligosaccharide and O-antigen) and rough-LPS (lacking the O-antigen part) (Konnova et al., 2008). In contrast to the wild-type, the $w z m$ mutant pattern showed diffuse bands of lower molecular mass (Fig. 2, arrow 3), confirming that the wzm mutation affects the LPS structure of $A$. brasilense Sp7. Other experiments, in which LPSs were

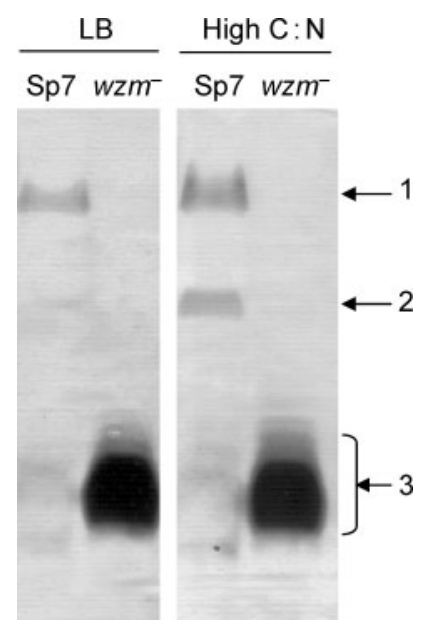

Fig. 2. SDS-PAGE of LPS extracted from A. brasilense Sp7 and wzm mutant grown in LB and high $\mathrm{C}: \mathrm{N}$ fructose media. Arrows indicate positions of bands that are discussed in the text. extracted with a commercial kit and analysed by DOCPAGE, showed similar results (not shown), supporting major LPS changes in the mutant strain relative to the wild-type.

We further assessed EPS production in the wzm mutant. In these and subsequent experiments, the high $\mathrm{C}: \mathrm{N}$ fructose medium described by Burdman et al. (1999) was used, since conditions of carbon-source excess and nitrogensource limitation induce EPS production by $A$. brasilense (del Gallo et al., 1989), and because we have used this medium in various studies aimed at characterizing extracellular polysaccharide synthesis and other related features of A. brasilense (Burdman et al., 1998, 1999, 2000b; Kadouri et al., 2002, 2003; Bahat-Samet et al., 2004).

Two experiments were carried out to determine the EPS concentration of the wzm mutant relative to the wild-type. The results of the two experiments were similar, and twoway ANOVA revealed that the effects of the experiments were not significant $(P=0.19)$; therefore, data from the two experiments were pooled for one analysis. No significant differences in EPS concentration were found between wildtype and wzm mutant strains under the tested conditions. The EPS concentrations were $519.6 \pm 28.2$ and $506.2 \pm 25.2 \mathrm{mg}$ EPS (g bacterial dry weight $)^{-1}$ (mean $\pm \mathrm{sE}$ ) for wild-type and mutant strains, respectively.

Two experiments were performed to determine the monosaccharide composition of the wzm mutant relative to the wild-type strain. The experiments gave similar results and overall, no dramatic differences were observed between strains in their monosaccharide composition (Table 1). Nevertheless, several differences were found; for instance, the relative concentration of fucose was two times higher in the EPS of the mutant than in that of the wild-type. In addition, the mutant EPS had slightly higher concentrations of glucose than that of the wild-type. In contrast, the EPS of the mutant strain showed galactose concentrations that were 1.9 times lower than those of the wild-type EPS (Table 1).

Table 1. Monosaccharide composition of EPSs extracted from $A$. brasilense Sp7 and wzm mutant strains, after $48 \mathrm{~h}$ of growth in high $\mathrm{C}: \mathrm{N}$ fructose medium

Results represent average \pm range of the relative presence of each sugar (percentage) from two independent experiments.

\begin{tabular}{|lrc|}
\hline Sugar & \multicolumn{1}{c|}{ Sp7 } & wzm mutant \\
\hline Rhamnose & $2.1 \pm 0.6$ & $2.4 \pm 1.9$ \\
Fucose & $1.3 \pm 0.5$ & $2.6 \pm 0.2$ \\
Ribose & $2.5 \pm 0.3$ & $1.7 \pm 1.6$ \\
Arabinose & $1.4 \pm 0.2$ & $1.1 \pm 0.1$ \\
Xylose & $1.9 \pm 1.2$ & $1.6 \pm 0.2$ \\
Mannose & $28.8 \pm 1.0$ & $25.9 \pm 4.2$ \\
Galactose & $15.2 \pm 0.1$ & $8.1 \pm 4.0$ \\
Glucose & $46.8 \pm 1.3$ & $56.7 \pm 0.6$ \\
\hline
\end{tabular}


Wild-type and mutant strains were also grown on solid high $\mathrm{C}: \mathrm{N}$ medium in the presence of Congo red or calcofluor white. Both strains reacted similarly with calcofluor white (results not shown); however, only the wild-type strain showed positive staining with Congo red after $48 \mathrm{~h}$ of growth. Differences in Congo red staining between wild-type and mutant colonies became stronger after $72 \mathrm{~h}$ of growth due to stronger staining in wild-type colonies (results not shown).

\section{Microscopic characterization of the wzm mutant}

Observations of cells grown for $24 \mathrm{~h}$ in high C: $\mathrm{N}$ fructose medium by phase-contrast microscopy revealed substantial differences between the mutant and wild-type. While wildtype cells looked round and fat with visible polyhydroxybutyrate (PHB) granules (Fig. 3a), the cells of the wzm mutant looked thinner and longer than the wild-type cells, with no visible $\mathrm{PHB}$ granules (Fig. $3 \mathrm{~b}$ ). In addition, long chains of cells were observed in the mutant but not in the wild-type. Qualitative microscopy observations also revealed that the mutant strain appears to be affected in swimming motility: while Sp7 cells exhibited a typical, rapid swimming motility, the wzm mutant cells moved slightly more slowly and in a wave-like pattern.

SEM revealed that many of the $S \mathrm{p} 7$ cells were arranged in microaggregates (Fig. 3c), whereas most of the wzm mutant cells were individually distributed (Fig. 3d). In addition, extracellular microfibrils were produced by the wild-type (Fig. 3e; white arrows) but not by the mutant (Fig. 3f). These microfibrils have been suggested to be involved in cell aggregation (Burdman et al., 1998). Finally, the wzm mutant cells showed different sizes and shapes as well as some variety in surface appearance (Fig. 3f), as opposed to the uniformity of the wild-type cells (Fig. 3e). Interestingly, in contrast to most wild-type cells, which lost their polar flagella during the SEM preparation procedure (Fig. 3c), most mutant cells retained their polar flagella (Fig. 3d, f). This difference could be due to alterations caused by the $w z m$ mutation in cell envelope structural integrity, as it is known that LPS plays an important role in OM stabilization and in folding and assembly of bacterial OM proteins (de Cock et al., 1999; Michel et al., 2000).
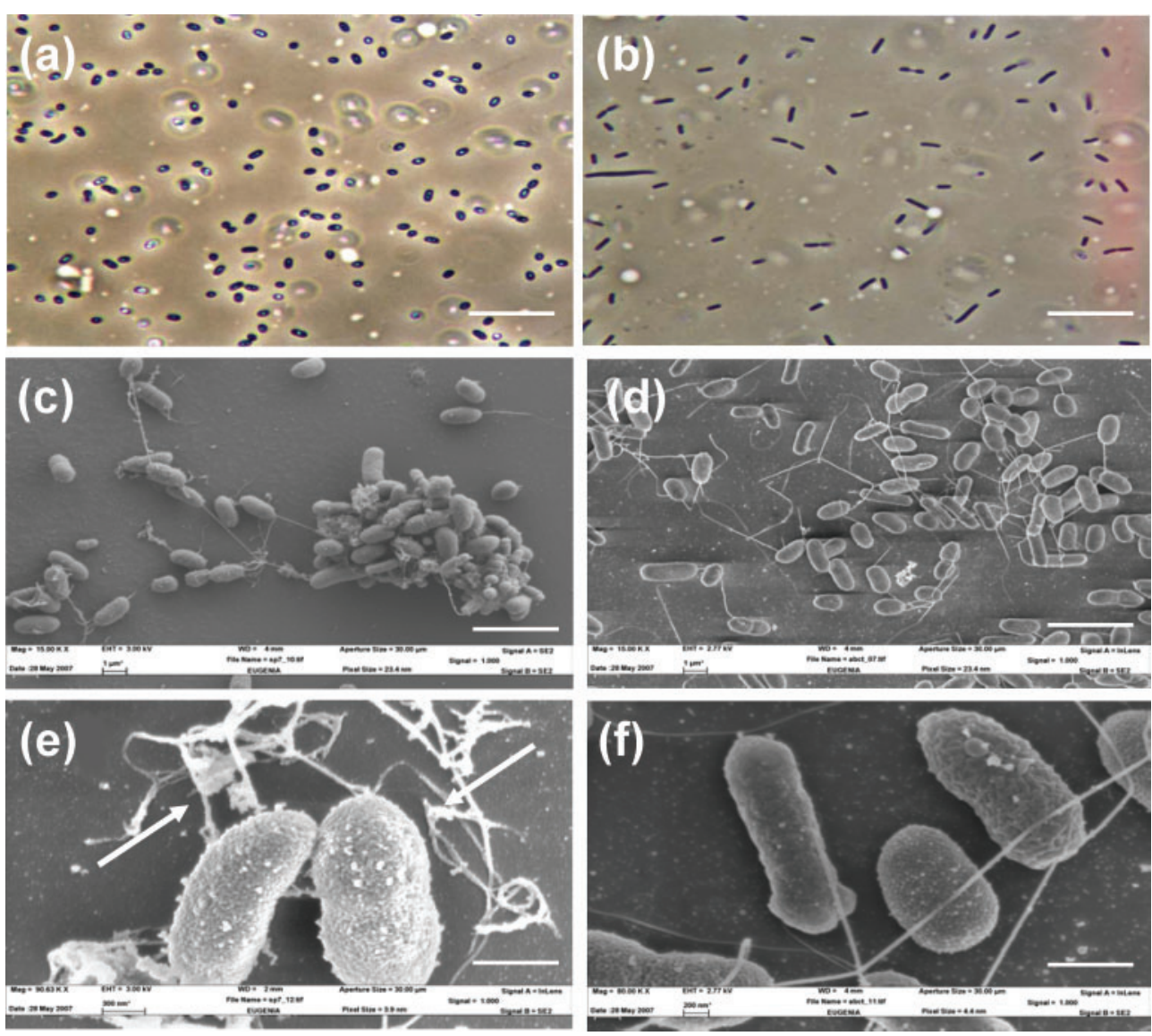

Fig. 3. Phase-contrast $(\mathrm{a}, \mathrm{b})$ and scanning electron (c-f) micrographs of $A$. brasilense $\mathrm{Sp} 7(\mathrm{a}, \mathrm{c}$ and $\mathrm{e})$ and the wzm mutant (b, $\mathrm{d}$ and $\mathrm{f}$ ) after $24 \mathrm{~h}$ of growth in high $\mathrm{C}: \mathrm{N}$ fructose medium. White arrows in (e) indicate extracellular microfibrils produced by the wild-type. Bars: (a, b), $9.5 \mu \mathrm{m}$; (c, d), $3.5 \mu \mathrm{m}$; (e), $0.57 \mu \mathrm{m} ;(\mathrm{f}), 0.76 \mu \mathrm{m}$. 


\section{Characterization of wzm mutant growth}

As part of the wzm mutant characterization, the strain was compared with the wild-type for its ability to grow in the presence of different sugars and malic acid as sole carbon sources. In these experiments, mutant and wild-type strains were grown for $48 \mathrm{~h}$ in high $\mathrm{C}: \mathrm{N}$ media containing the tested carbon sources at $37 \mathrm{mM}$. Differences in growth intensity were observed among the strains with most of the carbon sources tested (Table 2). Wild-type cells were able to utilize all carbon sources tested. In contrast, the mutant strain was not able to grow on L-rhamnose or D-arabinose as sole carbon sources. In addition, the mutant strain grew to a lesser extent (lower OD values) than the wild-type strain on D-fructose, D-mannose, D-glucose, D-xylose and L-arabinose (Table 2). On DL-malic acid and on Dgalactose, the mutant strain grew to an OD similar to that of the wild-type. However, the lag phases of the mutant were longer than those observed for the wild-type on these and most of the other tested carbon sources. The exception was L-arabinose: although the wild-type grew to a higher OD than the mutant, it had a more prolonged lag phase (27 h compared with 18-24 h for the mutant). Representative growth curves of the wzm mutant and wild-type in some of the carbon sources (malic acid, Dxylose and D-arabinose) are shown in Fig. 4.

\section{Assessment of resistance of the wzm mutant to different stresses}

LPSs contribute to the structural integrity of the cell envelope of Gram-negative bacteria and are also involved in diverse interactions between bacterial cells and the environment (Lüderitz et al., 1982). As the wzm mutation affected LPS in A. brasilense Sp7, we examined whether the

Table 2. Growth of $A$. brasilense Sp7 and wzm mutant strains in high $\mathrm{C}: \mathrm{N}$ medium with different carbon sources at $37 \mathrm{mM}$

Cultures were grown for $48 \mathrm{~h}$ and results express growth level based on $\mathrm{OD}$ values at the end of the growth period:,- no growth; + , final $\mathrm{OD}_{600}=0.1-0.3$ (moderate growth); ++ , final $\mathrm{OD}_{600}>0.3$. Differences between strains in lag-phase extension are discussed in the text.

\begin{tabular}{|lcc|}
\hline Carbon source & Sp7 & wzm mutant \\
\hline D-Fructose & ++ & + \\
DL-Malic acid & ++ & ++ \\
D-Mannose & ++ & + \\
D-Glucose & ++ & + \\
D-Galactose & ++ & ++ \\
L-Rhamnose & ++ & - \\
D-Xylose & ++ & + \\
D-Arabinose & ++ & - \\
L-Arabinose & ++ & + \\
\hline
\end{tabular}
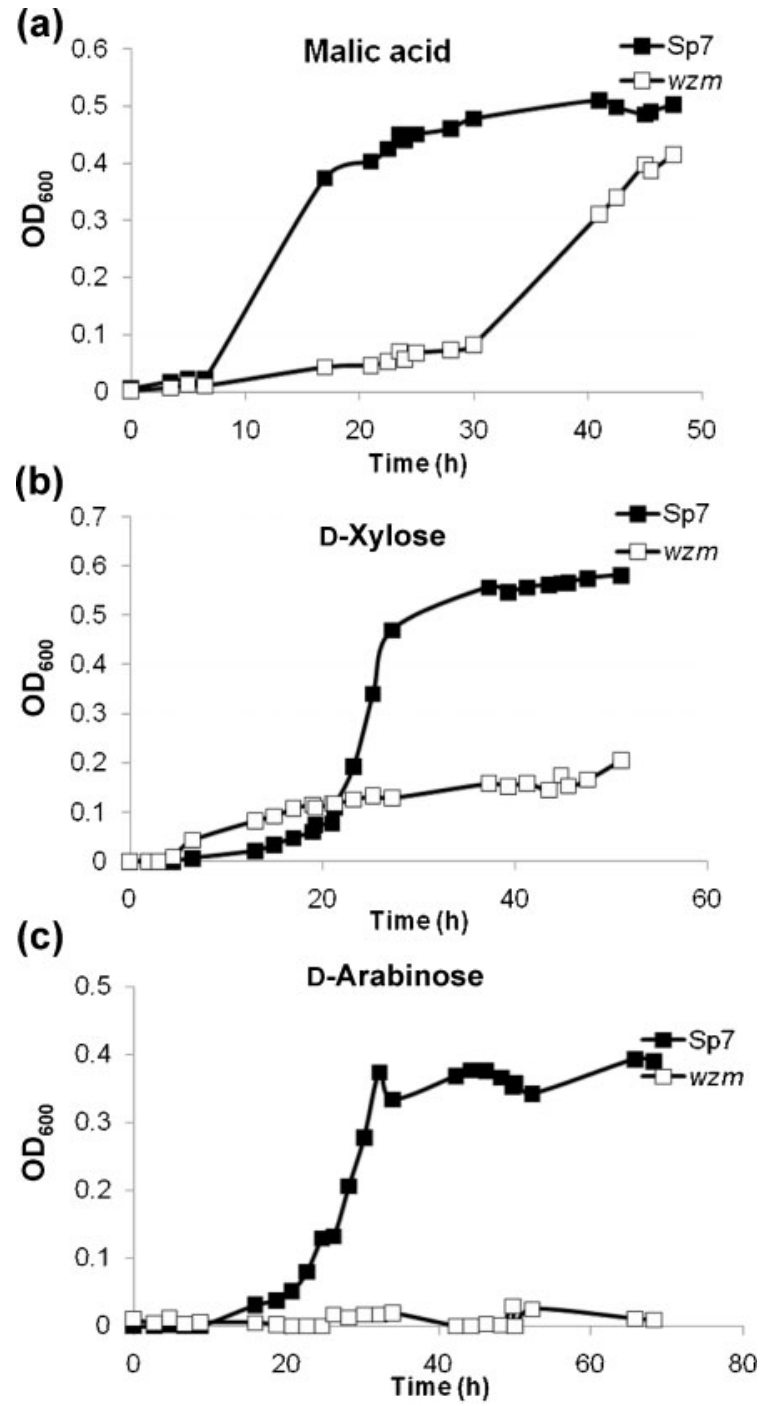

Fig. 4. Representative growth curves (of two with similar results) of $A$. brasilense $\mathrm{Sp} 7$ and wzm mutant in high $\mathrm{C}: \mathrm{N}$ medium with different carbon sources: (a) malic acid; (b) D-xylose; (c) Darabinose.

mutant strain exhibits a different response to diverse stresses relative to the wild-type. Interestingly, these experiments revealed that the mutant was more resistant than the wild-type to several stresses. For instance, following exposure of bacteria to heat $\left(55^{\circ} \mathrm{C}\right)$, viable cells of the wild-type declined more rapidly than those of the wzm mutant: after $1 \mathrm{~h}$ of exposure, only $0.01-0.02 \%$ of the wild-type bacteria were still alive, whereas at the same time point, 3-6\% of the mutant cells were still alive (percentages represent ranges of survival from three different experiments with similar results; data from a representative experiment are shown in Fig. 5a). The mutant also showed significantly higher survival rates than the wild-type in response to glycerol-induced osmotic shock and to osmotic 

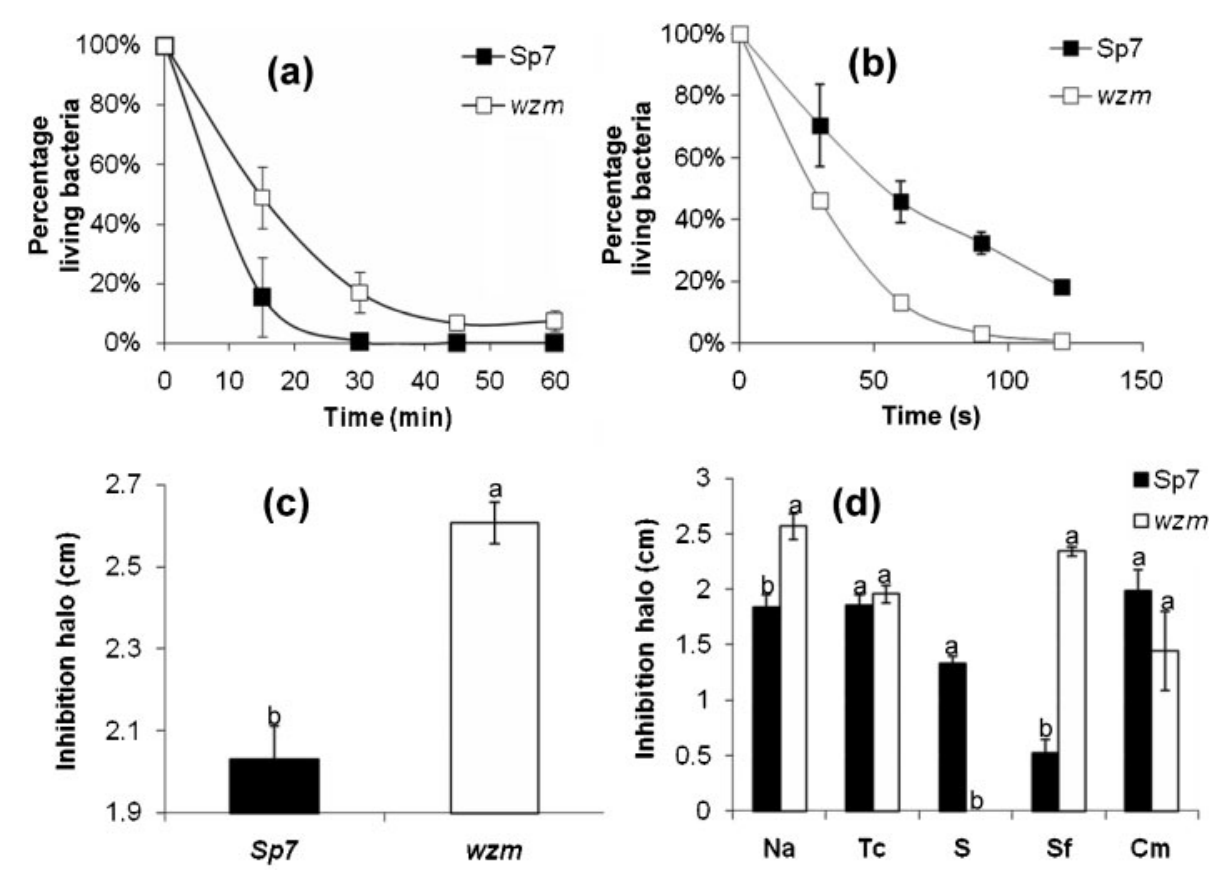

Fig. 5. Exposure of $A$. brasilense Sp7 and wzm mutant to different stresses and antibiotics: (a) heat (55 $\left.{ }^{\circ} \mathrm{C}\right)$; (b) UV radiation; (c) $1.5 \%$ hydrogen peroxide; (d) antibiotics [ $\mathrm{Na}$, nalidixic acid $\left(50 \mathrm{mg} \mathrm{ml}^{-1}\right)$; Tc, tetracycline $\left(10 \mu \mathrm{g} \mathrm{ml} \mathrm{l}^{-1}\right) ; \mathrm{S}$, streptomycin $\left(25 \mu \mathrm{g} \mathrm{ml}^{-1}\right)$; Sf, sulfafurazol $\left(100 \mu \mathrm{g} \mathrm{ml}^{-1}\right) ; \mathrm{Cm}$, chloramphenicol $\left.\left(25 \mu \mathrm{g} \mathrm{ml}^{-1}\right)\right]$. Data represent mean $\pm \mathrm{SD}$ of representative experiments (of three with similar results). Different letters indicate significant differences $(P=0.05)$ between wild-type and mutant strains.

pressure induced by high concentrations of fructose, as well as to desiccation and starvation (Table 3).

In contrast, the wzm mutant exhibited higher sensitivity than the wild-type strain to UV radiation: while 11-18\% of the wild-type cells survived after $120 \mathrm{~s}$ of exposure to UV radiation, only $0.7-0.8 \%$ of the mutant cells survived under the same conditions (ranges from three different experiments with similar results; data from a representative experiment are shown in Fig. 5b). Similarly, the mutant strain exhibited significantly higher sensitivity than the wild-type to hydrogen peroxide (a representative experiment of three with similar results is shown in Fig. 5c).

The mutant was also more sensitive than the wild-type to saline stress. Neither strain was able to grow in the presence of 400 or $500 \mathrm{mM} \mathrm{NaCl}$. However, while the wild-type was able to grow in the presence of $300 \mathrm{mM} \mathrm{NaCl}\left(\mathrm{OD}_{600} \sim 0.5\right.$ after $48 \mathrm{~h}$ of growth), the wzm mutant was not able to grow under these conditions. No differences were observed between wild-type and wzm mutant in their ability to grow on high $\mathrm{C}: \mathrm{N}$ media supplemented with $0.01 \%$ SDS (not shown).

\section{Assessment of the response of the wzm mutant to antibiotics}

Alterations in the structural integrity of the cell envelope caused by defective LPS may affect the response of bacteria to antibiotics. Indeed, differences in sensitivity to antibiotics were observed between wzm mutant and wild-type

Table 3. Survival rates (in percent) of $A$. brasilense wild-type $\mathrm{Sp} 7$ and wzm mutant in response to exposure to osmotic shock, desiccation, starvation and osmotic pressure

Different letters indicate significant differences $(P=0.05)$ between strains under the different treatments.

\begin{tabular}{|c|c|c|c|c|c|}
\hline \multirow[t]{2}{*}{ Strain } & \multirow[t]{2}{*}{ Osmotic shock } & \multirow[t]{2}{*}{ Desiccation } & \multirow[t]{2}{*}{ Starvation } & \multicolumn{2}{|c|}{ Osmotic pressure } \\
\hline & & & & $1 \mathrm{M}$ fructose & $2 \mathrm{M}$ fructose \\
\hline Sp7 & $0.3 \pm 0.1 \mathrm{a}$ & $4.1 \pm 2.2 \mathrm{a}$ & $2.4 \pm 1.3 \mathrm{a}$ & $0.004 \pm 0.001 \mathrm{a}$ & $0.001 \pm 0.001 b$ \\
\hline$w z m$ mutant & $15.1 \pm 0.9 b$ & $15.0 \pm 2.6 b$ & $14.9 \pm 0.4 b$ & $38.2 \pm 48.6 b$ & $2.5 \pm 3.1 b$ \\
\hline
\end{tabular}


strains (Fig. 5d). The wild-type was significantly less susceptible than the mutant to sulfafurazol and nalidixic acid. Interestingly, in contrast to the wild-type strain, which was susceptible to streptomycin, the mutant strain was found to be resistant to this antibiotic. Under the tested conditions, no significant differences were observed between the strains in their response to tetracycline and chloramphenicol (Fig. 5d), although with the latter, reduced inhibition haloes were consistently measured for the mutant relative to the wild-type strain.

\section{OMP profile of the wzm mutant}

The pleiotropic phenotype of the wzm mutant, including its differential response under diverse stress conditions relative to the wild-type, could be due, at least in part, to changes in the composition of OMPs. To assess this possibility, we compared the OMP pattern of the mutant with that of the wild-type by SDS-PAGE. Two independent OMP extractions of wild-type and mutant strains were performed showing similar results. SDS-PAGE revealed substantial differences between the strains (Fig. 6). These included the absence or significant reduction of wild-type bands in the mutant profile, such as the band representing the typical A. brasilense $38.7 \mathrm{kDa}$ major OMP, OmaA (Burdman et al., 2000a) (Fig. 6, upper arrow). Instead of this protein, a strong band with slightly higher mobility was observed in the mutant profile (Fig. 6, lower arrow). On the other hand, several other bands were observed in the profile of the wzm mutant and were apparently absent or reduced in the wild-type profile. It is likely, however, that these differences were mainly due to the dominance of the OmaA protein in the OMP profile of the wild-type, but not of the mutant, which led to a significant relative reduction of other bands in the former. In support of this,

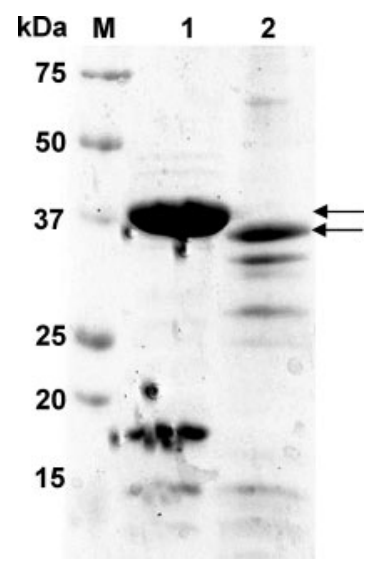

Fig. 6. SDS-PAGE of OMPs of $A$. brasilense Sp7 and wzm mutant (lanes 1 and 2, respectively). $M$, prestained marker (Precision Plus Protein Standards, Bio-Rad). Arrows indicate the position of bands discussed in the text. these bands had already been observed in previous studies of A. brasilense OMPs (Burdman et al., 1999)

\section{Plant growth promotion and adhesion to seeds and roots}

We also assessed the ability of the wzm mutant to adhere to sweet corn seeds and roots and to induce the growth of these plants. No significant differences in adhesion to seeds and roots were observed between mutant and wild-type strains under the tested conditions. The average number of cells that could be extracted from the seeds after $3 \mathrm{~h}$ of incubation was $2.5 \times 10^{7}$ and $5 \times 10^{7}$ c.f.u. $\mathrm{ml}^{-1}$ for wildtype and mutant, respectively, and these differences were not significant. Similarly, the strains did not differ in the number of cells extracted from inoculated roots, which varied between $10^{6}$ and $10^{7}$ c.f.u. (g root wet weight) ${ }^{-1}$ in the different experiments.

Under the tested conditions, mutant and wild-type strains did not differ in their growth promotion-inducing ability. In the different experiments, both strains consistently induced higher weight of roots and shoots, as well as longer roots and shoots, in comparison with non-inoculated plants (results not shown), although the differences between inoculated and non-inoculated plants were not statistically significant in the different experiments.

\section{DISCUSSION}

In this study, we characterized a mutant strain of $A$. brasilense Sp7 with impairment in wzm (pRhico062), a gene encoding an inner-membrane protein of an $\mathrm{ABC}$ transporter. $w z m$ is located in the pRhico plasmid, in a cluster of genes involved in the synthesis of surface polysaccharides (Vanbleu et al., 2004). Indeed, sequence analyses of the predicted $w z m$ product indicate that this gene belongs to the ABC-2-type transporter subfamily, which contains transporters involved in the export of surface polysaccharides (Reizer et al., 1992). In agreement with this, we demonstrated that the wzm mutant is affected in LPS synthesis, and is altered in its EPS monosaccharide composition relative to the wild-type.

In addition to the integral inner-membrane component, $\mathrm{ABC}$ transporters are composed of a hydrophilic ATPbinding protein. Closely linked to $w z m$, there is a gene annotated as wzt (pRhico064) that encodes a typical ATPbinding protein. It is reasonable to speculate that the wzt product is the concomitant protein of Wzm in $A$. brasilense, although this hypothesis has yet to be experimentally validated. Homologous Wzm-Wzt systems have been shown to be involved in export of the O-antigen portion of the LPS in several Gram-negative bacterial species (Guo et al., 1996; Saigí et al., 1999; Feng et al., 2004). In our study, the wzm mutant colonies had a rough appearance compared with the smoothness of those of the wild-type. This switch from smooth (S) to rough (R) 
colonies occurs in several Gram-negative mutants that fail to add the O-antigen portion to the LPS (Kustos et al., 2000a, b; Godowski, 2005; Wolf \& Goldberg, 2006). However, from our study, we cannot conclude that Wzm is involved in O-antigen export in A. brasilense, as we were not able to detect in the mutant the intermediate molecular mass band that is typical of the A. brasilense Sp7 R-LPS, consisting of lipid A and core oligosaccharide (Konnova et al., 2008). Therefore, the LPS profile of the mutant strain, characterized by diffuse, low-molecular-mass bands, suggests that in A. brasilense, Wzm could also be involved in export of the core oligosaccharide.

Upstream of and in close proximity to $w z m$ and $w z t$, there are other genes, pRhico046 to pRhico061, which are likely to be involved in LPS biosynthesis and assembly (Vanbleu et al., 2004). For example, genes pRhico046 to pRhico050 are involved in the biosynthesis of dTDP-rhamnose. In $A$. brasilense $\mathrm{Cd}$, rhamnose, as well as galactose and mannose, have been found to be components of the LPS (Konnova et al., 2006). Fedonenko et al. (2002) found an O-specific pentasaccharide composed of repeating units of D-rhamnose in A. brasilense Sp245. Jofré et al. (2004) isolated an A. brasilense Cd mutant impaired in rhamnose production and found that it produces LPS with small traces of this specific sugar.

The wzm mutant and wild-type strains did not differ significantly in their EPS amount, but several differences were observed between them in EPS monosaccharide composition. Wild-type and mutant strains also differed in their ability to bind to Congo red, a property that is often related to EPS composition. Earlier findings have shown the presence of identical epitopes in A. brasilense LPS and EPS, leading to the hypothesis that EPS is formed by the excreted O-specific fragments of LPS (Matora et al., 1995; Katzy et al., 1998). Whether this phenomenon, which has also been proposed for other bacterial species (Kenne \& Lindberg, 1983; Whitfield et al., 1994), occurs in A. brasilense, and the biological relevance of the alterations in EPS by the wzm mutation, still need to be assessed.

The wzm mutant showed pleiotropic phenotypic alterations relative to the wild-type. In agreement with our findings, Bliss et al. (1996) and Cuthbertson et al. (2005) reported diverse changes in cell morphology of E. coli mutants defective in kpsT and wzt, which encode ATPbinding cassettes of EPS and LPS transporters, respectively. The latter is similar to the $A$. brasilense wzt gene (pRhico064). Microscopic observations revealed differences in cell shape and size, and in the presence or absence (in Sp7 and the mutant strain, respectively) of extracellular microfibrils connecting the cells. The occurrence of such a fibrillar matrix, likely involved in cell aggregation and root attachment, has previously been reported in A. brasilense (del Gallo et al., 1989; Katupitiya et al., 1995; Burdman et al., 1998; Puente et al., 1999; Galindo Blaha \& Schrank, 2003). In addition to the differences in EPS composition, the differences in fibrillar matrix production between the strains could also contribute to their differential staining with Congo red.

Using random omegon-Km mutagenesis, Katzy et al. (1998) isolated six LPS mutants of A. brasilense Sp245. Interestingly, although the exact insertion of the omegon$\mathrm{Km}$ cassette was not identified, in all mutants the cassette was detected in the $120 \mathrm{MDa}$ plasmid (p120). In agreement with these findings, in a further study it was shown that several fragments of this plasmid hybridize with the Sp7 pRhico plasmid (Petrova et al., 2005) that, as already mentioned, contains several genes involved in the synthesis of surface polysaccharides, including LPS. In our study, the wzm mutant appeared to be affected in swimming motility compared with the wild-type strain. Loss of wild-type motility was also reported for one of the Sp245 LPS mutants (Katzy et al., 1998).

LPSs are major components of the OM of Gram-negative bacteria, and the structural integrity of the OM may affect the response of bacteria to diverse antibiotics (Nikaido \& Vaara, 1985; Sukupolvi \& Vaara, 1989). Indeed, differences in sensitivity to some tested antibiotics were observed between the wild-type and mutant, with the most pronounced difference being the response to streptomycin, to which the wzm mutant was completely resistant under the tested conditions, in contrast to the wild-type, which was susceptible. In agreement with our findings, Bryan et al. (1984) reported that conversion of the smooth LPS to the rough LPS phenotype increased the resistance of Pseudomonas aeruginosa to aminoglycoside antibiotics, including streptomycin. In contrast, the Sp7 wzm mutant was more susceptible than the wild-type to nalidixic acid. Similarly, mutants of Stenotrophomonas maltophilia that produce less LPS and shorter O polysaccharide chains than the wild-type have been shown to be more susceptible to this antibiotic (McKay et al., 2003).

While the exact mechanisms by which LPSs affect antibiotic susceptibility have not been fully discerned, they have been attributed to differences in OM permeability as a result of a disruption in the conformation of OMPs such as associated porins, which limits their ability to transport molecules (Hirai et al., 1986; Moniot-Ville et al., 1991; Turcotte et al., 1997; Yokota \& Fujii, 2007). For instance, in $P$. aeruginosa, the mechanisms that lead to an increased resistance to aminoglycoside antibiotics include impaired OM uptake and reduced active transport (El'Garch et al., 2007). Our study revealed substantial differences in OMP composition between wild-type and wzm mutant strains, which could be involved in a differential response to antibiotics. LPS-defective mutants are often compromised in the assembly of OMPs (Zuleta et al., 2003). Nurminen et al. (1997) reported an E. coli LPS-defective mutant that showed reduced levels of the OmpF porin. In agreement with our study, Rahaman et al. (1998) found remarkable differences between an LPS-defective mutant of E. coli and the wild-type in their OMP patterns: in the mutant strain, the level of OmpC was reduced, OmpF was almost absent, 
and instead of OmpA, a band with higher mobility was observed. Similarly, significant differences in OMP patterns between wild-type and LPS-defective mutants have been observed in other species, such as Burkholderia cepacia (Rajyaguru \& Muszynski, 1997) and Proteus penneri (Kustos et al., 2000a, b).

Some OMPs function as substrate-specific porins, including some that are responsible for uptake of specific sugars (Koebnik et al., 2000). Therefore, differences in OMP composition between the wild-type and the wzm mutant could also be responsible for the observed differences in their growth ability with diverse sugars as carbon sources (for instance, the lack of growth of the mutant on Lrhamnose and D-arabinose, in contrast to the wild-type). However, little is known about the physiological role of $A$. brasilense OMPs. Thus, the relationship between the effects of the wzm mutation in OMP composition and the observed pleiotropic phenotypic changes of the $w z m$ mutant strain (including differences in antibiotic resistance and growth) are still to be elucidated.

LPS has been shown to contribute to bacterial survival under diverse stress conditions. For instance, Touze et al. (2004) used several mutants impaired in LPS biosynthesis to demonstrate an important role for O-antigen in stress adaptation of Erwinia chrysanthemi, and Thomsen et al. (2003) showed that reduced amounts of LPS affect the stress tolerance and virulence of Salmonella enterica. Bacteria have to adapt to fluctuations in salinity and osmolarity in the environment. To cope with this, they accumulate osmolytes such as potassium ions, glycine betaine (GB), proline and proline betaine, among others (Chowdhury et al., 2007). Riou et al. (1991) showed the occurrence of a GB-binding protein in the periplasmic cavity of A. brasilense Sp7. Hartman et al. (1991) demonstrated the ability of some Azospirillum species to convert choline to GB. As already mentioned, LPSs play an essential role in the integrity of the OM; therefore, it is possible that the wzm mutant is not able to maintain sufficient amounts of GB in the cell, thus contributing to an enhanced susceptibility to elevated levels of $\mathrm{NaCl}$ in comparison with the wild-type, as observed in our study. In agreement with our findings, LPS-defective mutants of Caulobacter crescentus have also been found to be more susceptible to salinity than the wild-type strain (Zuleta et al., 2003).

Interestingly, although likely possessing a defective OM, the wzm mutant cells were able to survive under certain unfavourable conditions at higher levels than the wild-type. It is known that in addition to LPSs, EPSs play a role in bacterial survival under diverse stress conditions such as heat (Mao et al., 2001), UV radiation (Pattanaik et al. 2007; Wang et al., 2007), desiccation (Roberson \& Firestone, 1992; Ophir \& Gutnick, 1994), starvation (Holmström \& Kjelleberg, 1999; Wai et al., 1999), oxidation and osmotic shock (Wai et al., 1999; Chen et al., 2004). As has been stated, the biological relevance (including effects on stress response) of the differences found between the wzm mutant and the wild-type strain in their EPS composition still needs to be elucidated.

As A. brasilense is a plant growth-promoting bacterium, it was natural to ask whether the wzm mutation that leads to a pleiotropic phenotye also affects its ability to adhere to the root surface and to induce plant growth promotion. Plant root colonization by Azospirillum spp. is a process that involves extracellular proteins and polysaccharides (Burdman et al., 2000b). Also, an A. brasilense Cd mutant affected in rhamnose production and having an altered LPS has been shown to have defective root colonization ability (Jofré et al., 2004). Therefore, it was reasonable to hypothesize that the wzm mutant strain is compromised in its ability to adhere to plant roots. On the other hand, Arunakumari et al. (1992) reported that a transposon mutant of $A$. brasilense $\mathrm{Cd}$, which lost the ability to aggregate, was able to efficiently colonize the plant root; and Bastarrachea et al. (1988) found that A. brasilense and Azospirillum lipoferum mutants that stained poorly on Congo red plates were able to anchor to and colonize plant roots.

In the experiments performed with sweet corn, under the tested conditions, there were no significant differences between mutant and wild-type strains in plant growth promotion and in adhesion to seeds and roots. It may be that in the mutant, the absence of microfibrils allows for better extraction of cells from the root surface compared with the wild-type. In addition, microaggregates formed by the wild-type cells but not by the mutant, or chains of cells formed by the wzm mutant but not by the wild-type, can lead to a bias of several orders of magnitude in the number of counted cells adhered to the plant root. Experiments using wild-type and mutant strains labelled with a genetic marker (such as lac $Z$ ) that allows direct observation of the bacteria on the roots could be used in the future to sidestep the above bias and give a more precise answer to this question.

Finally, it is important to mention that the plant growth promotion and adhesion experiments were conducted under standard, optimal conditions. Jofré et al. (1998) reported that the anchoring ability of $A$. brasilense to maize and wheat roots is negatively affected under saline stress, and that impairment of anchoring ability correlates with alterations in EPSs and LPSs. Therefore, we cannot exclude the possibility that differences between the wild-type and mutant strains in root adhesion and plant growth promotion might occur under other experimental conditions, including stress.

\section{ACKNOWLEDGEMENTS}

Special thanks to Y. Tekoah, Head of the Center for Glycobiology at Ben-Gurion University of the Negev (Beer-Sheva, Israel), and his team for helping with the EPS analyses. Special thanks also to O. Yeger, the manager of the Irving and Cherna Moskowitz Center for Nano and Bio-Nano Imaging at the Weizmann Institute of Science 
(Rehovot, Israel), for her contribution to the electron microscopy. We also thank J. Vanderleyden and E. Vanbleu for their valuable suggestions. This research was supported by The Israel Science Foundation funded by The Academy of Sciences and Humanities (grant 253/05).

\section{REFERENCES}

Albersheim, P., Nevins, D. J., English, P. D. \& Karr, A. (1967). A method for the analysis of sugars in plant cell-wall polysaccharides by gas-liquid chromatography. Carbohydr Res 5, 340-345.

Altschul, S. F., Madden, T. L., Schaffer, A. A., Zhang, J., Zhang, Z., Miller, W. \& Lipman, D. J. (1997). Gapped BLAST and PSI-BLAST: a new generation of protein database search programs. Nucleic Acids Res 25, 3389-3402.

Arunakumari, A., Lamm, R. B. \& Neyra-Estens, C. A. (1992). Changes in cell surface properties of azospirilla in relation to cell pleomorphism and aggregation. Symbiosis 13, 291-305.

Bahat-Samet, E., Castro-Sowinski, S. \& Okon, Y. (2004). Arabinose content of extracellular polysaccharide plays a role in cell aggregation of Azospirillum brasilense. FEMS Microbiol Lett 237, 195-203.

Bastarrachea, F., Zamudio, M. \& Rivas, R. (1988). Non-encapsulated mutants of Azospirillum brasilense and Azospirillum lipoferum. Can J Microbiol 34, 24-29.

Bliss, J. M., Garon, C. F. \& Silver, R. P. (1996). Polysialic acid export in Escherichia coli Kl: the role of KpsT, the ATP-binding component of an $\mathrm{ABC}$ transporter, in chain translocation. Glycobiology 6, 445-452.

Brink, B. A., Miller, J., Carlson, R. W. \& Noel, K. D. (1990). Expression of Rhizobium leguminosarum CFN42 genes for lipopolysaccharide in strains derived from different $R$. leguminosarum soil isolates. J Bacteriol 172, 548-555.

Bryan, L. E., O’Hara, K. \& Wong, S. (1984). Lipopolysaccharide changes in impermeability-type aminoglycoside resistance in Pseudomonas aeruginosa. Antimicrob Agents Chemother 26, 250-255.

Burdman, S., Jurkevitch, E., Schwatsburd, B., Hampel, M. \& Okon, Y. (1998). Aggregation in Azospirillum brasilense: effects of chemical and physical factors and involvement of extracellular components. Microbiology 144, 1989-1999.

Burdman, S., Jurkevitch, E., Schwartsburd, B. \& Okon, Y. (1999). Involvement of outer membrane proteins in aggregation of Azospirillum brasilense. Microbiology 145, 1145-1152.

Burdman, S., De Mot, R., Vanderleyden, J., Okon, Y. \& Jurkevitch, E. (2000a). Identification and characterization of the omaA gene encoding the major outer membrane protein of Azospirillum brasilense. DNA Seq 11, 225-237.

Burdman, S., Jurkevitch, E., Soria-Diaz, M. E., Serrano, A. M. G. \& Okon, Y. (2000b). Extracellular polysaccharide composition of Azospirillum brasilense and its relation with cell aggregation. FEMS Microbiol Lett 189, 259-264.

Burdman, S., Okon, Y. \& Jurkevitch, E. (2000c). Surface characteristics of Azospirillum brasilense in relation to cell aggregation and attachment to plant roots. Crit Rev Microbiol 26, 91-110.

Cava, J. R., Elias, P. M., Turowski, L. D. A. \& Noel, K. D. (1989). Rhizobium leguminosarum CFN42 genetic regions encoding lipopolysaccharide structures essential for complete nodule development on bean plants. J Bacteriol 171, 8-15.

Chen, J., Lee, S. M. \& Mao, Y. (2004). Protective effect of Escherichia coli O157:H7 exopolysaccharide colanic acid to osmotic shock and oxidative stress. Int J Food Microbiol 93, 281-286.

Chowdhury, S. P., Nagarajan, T., Tripathi, R., Mishra, M. N., Le Rudulier, D. \& Tripathi, A. K. (2007). Strain-specific salt tolerance and osmoregulatory mechanisms in Azospirillum brasilense. FEMS Microbiol Lett 267, 72-79.

Creus, C. M., Graziano, M., Casanovas, E. M., Pereyra, M. A., Simontacchi, M., Puntarulo, S., Barassi, C. A. \& Lamattina, L. (2005). Nitric oxide is involved in the Azospirillum brasilense-induced lateral root formation in tomato. Planta 221, 297-303.

Croes, C., Van Bastelaere, E., DeClercq, E., Eyers, M., Vanderleyden, J. \& Michiels, K. (1991). Identification and mapping of loci involved in motility, adsorption to wheat roots, colony morphology, and growth in minimal medium on the Azospirillum brasilense Sp7 90-MDa plasmid. Plasmid 26, 83-93.

Cuthbertson, L., Powers, J. \& Whitfield, C. (2005). The C-terminal domain of the nucleotide-binding domain protein Wzt determines substrate specificity in the ATP-binding cassette transporter for the lipopolysaccharide $\mathrm{O}$-antigens in Escherichia coli serotypes $\mathrm{O} 8$ and O9a. J Biol Chem 280, 30310-30319.

Davidson, A. L. (2002). Mechanism of coupling of transport to hydrolysis in bacterial ATP-binding cassette transporters. J Bacteriol 184, 1225-1233.

de Cock, H., Brandenburg, K., Wiese, A., Holst, O. \& Seydel, U. (1999). Non-lamellar structure and negative charges of lipopolysaccharides required for efficient folding of outer membrane protein PhoE of Escherichia coli. J Biol Chem 274, 5114-5119.

del Gallo, M., Negi, M. \& Neyra, C. A. (1989). Calcofluor- and lectinbinding exocellular polysaccharides of Azospirillum brasilense and Azospirillum lipoferum. J Bacteriol 171, 3504-3510.

de Troch, P. (1993). Bacterial surface polysaccharides in relation to plant interaction: a genetic and chemical study of Azospirillum brasilense. $\mathrm{PhD}$ thesis, Katholieke University te Leuven, Faculteit Landbouwkundige en Toegepaste Biologische Wetenschappen.

Dische, Z. (1962). General color reactions. Methods Carbohydr Chem 1, 477-479.

Dobbelaere, S., Croonenborghs, A., Thys, A., Ptacek, D., Vanderleyden, J., Dutto, P., Lambandera-Gonzalez, C., CaballeroMellado, J., Aguirre, J. F. \& other authors (2001). Responses of agronomically important crops to inoculation with Azospirillum. Aust J Plant Physiol 28, 871-879.

El'Garch, F., Jeannot, K., Hocquet, D., Llanes-Barakat, C. \& Plésiat, P. (2007). Cumulative effects of several nonenzymatic mechanisms on the resistance of Pseudomonas aeruginosa to aminoglycosides. Antimicrob Agents Chemother 51, 1016-1021.

Fedonenko, Y. P., Zatonsky, G. V., Konnova, S. A., Zdorovenko, E. L. \& Ignatov, V. V. (2002). Structure of the O-specific polysaccharide of the lipopolysaccharide of Azospirillum brasilense Sp245. Carbohydr Res 337, 869-872.

Feng, L., Senchenkova, S. N., Yang, J., Shashkov, A. S., Tao, J., Guo, H., Cheng, J., Ren, Y., Knirel, Y. A. \& other authors (2004). Synthesis of the heteropolysaccharide $\mathrm{O}$ antigen of Escherichia coli $\mathrm{O} 52$ requires an $\mathrm{ABC}$ transporter: structural and genetic evidence. J Bacteriol 186, 4510-4519.

Figurski, D. H. \& Helinski, D. R. (1979). Replication of an origincontaining derivative of plasmid RK2 dependent on a plasmid function provided in trans. Proc Natl Acad Sci U S A 76, 1648-1652.

Galindo Blaha, C. A. \& Schrank, I. S. (2003). An Azospirillum brasilense Tn 5 mutant with modified stress response and impaired in flocculation. Antonie Van Leeuwenhoek 83, 35-43.

Godowski, P. J. (2005). A smooth operator for LPS responses. Nat Immunol 6, 544-546.

Guo, D., Bowden, M. G., Pershad, R. \& Kaplan, H. B. (1996). The Myxococcus xanthus rfbABC operon encodes an $\mathrm{ABC}$ transporter homolog required for $\mathrm{O}$-antigen biosynthesis and multicellular development. J Bacteriol 178, 1631-1639. 
Hartman, A., Prabhu, S. R. \& Galinski, E. A. (1991). Osmotolerance of diazotrophic rhizosphere bacteria. Plant Soil 137, 105-109.

Herschkovitz, Y., Lerner, A., Davidov, Y., Okon, Y. \& Jurkevitch, E. (2005). Azospirillum brasilense does not affect population structure of specific rhizobacterial communities of inoculated maize (Zea mays). Environ Microbiol 7, 1847-1852.

Hirai, K., Aoyama, H., Irikura, T., lyobe, S. \& Mitsuhashi, S. (1986). Differences in susceptibility to quinolones of outer membrane mutants of Salmonella typhimurium and Escherichia coli. Antimicrob Agents Chemother 29, 535-538.

Holguin, G., Patten, C. L. \& Glick, B. R. (1999). Genetics and molecular biology of Azospirillum. Biol Fertility Soils 29, 10-23.

Holmström, C. \& Kjelleberg, S. (1999). Marine Pseudoalteromonas species are associated with higher organisms and produce biologically active extracellular agents. FEMS Microbiol Ecol 30, 285-293.

Jofré, E., Fischer, S., Rivarola, V., Balegno, H. \& Mori, G. (1998). Saline stress affects the attachment of Azospirillum brasilense Cd to maize and wheat roots. Can J Microbiol 44, 416-422.

Jofré, E., Lagares, A. \& Mori, G. (2004). Disruption of dTDPrhamnose biosynthesis modifies lipopolysaccharide core, exopolysaccharide production, and root colonization in Azospirillum brasilense. FEMS Microbiol Lett 231, 267-275.

Kadouri, D., Burdman, S., Jurkevitch, E. \& Okon, Y. (2002). Identification and isolation of genes involved in poly $(\beta$-hydroxybutyrate) biosynthesis in Azospirillum brasilense and characterization of phbC mutant. Appl Environ Microbiol 68, 2943-2949.

Kadouri, D., Jurkevitch, E. \& Okon, Y. (2003). Involvement of the reserve material poly- $\beta$-hydroxybutyrate in Azospirillum brasilense stress endurance and root colonization. Appl Environ Microbiol 69, 3244-3250.

Katupitiya, S., Millet, J., Vesk, M., Viccars, L., Zeman, A., Lidong, Z., Elmerich, C. \& Kennedy, I. R. (1995). A mutant of Azospirillum brasilense $\mathrm{Sp} 7$ impaired in flocculation with a modified colonization pattern and superior nitrogen fixation in association with wheat. Appl Environ Microbiol 61, 1987-1995.

Katzy, E. I., Matora, L. Y., Serebrennikova, O. B. \& Scheludko, A. V. (1998). Involvement of a 120-Mda plasmid of Azospirillum brasilense Sp245 in the production of lipopolysaccharides. Plasmid 40, 73-83.

Kenne, L. \& Lindberg, B. (1983). Bacterial polysaccharides. In The Polysaccharides, pp. 287-365. Edited by G. O. Aspinall. Orlando, FL: Academic Press.

Koebnik, R., Locher, K. P. \& Van Gelder, P. (2000). Structure and function of bacterial outer membrane proteins: barrels in a nutshell. Mol Microbiol 37, 239-257.

Konnova, O. N., Burygin, G. L., Fedonenko, Y. P., Matora, L. Y., Pankin, K. E., Konnova, S. A. \& Ignatov, V. V. (2006). Chemical composition and immunochemical characteristics of the lipopolysaccharide of nitrogen fixing rhizobacterium Azospirillum brasilense Cd. Mikrobiologiia 75, 383-388 (in Russian).

Konnova, O. N., Boiko, A. S., Burygin, G. L., Fedorenko, Y. P., Matora, L. Y., Konnova, S. A. \& Ignatov, V. V. (2008). Chemical and serological studies of liposaccharides of bacteria of the genus Azospirillum. Mikrobiologiia 77, 350-357.

Kustos, I., Tóth, V., Kocsis, B., Kerepesi, I. \& Emoödy, L. \& Kilár, F. (2000a). Capillary electrophoretic analysis of wild type and mutant Proteus penneri outer membrane proteins. Electrophoresis 21, 30203027.

Kustos, I., Tóth, V., Kilár, F., Kocsis, B. \& Emoődy, L. (2000b). Effect of spontaneous and induced mutations on outer membrane proteins and lipopolysaccharides of Proteus penneri strain 357. In Genes and Proteins Underlying Microbial Urinary Tract Virulence - Basic Aspects and Applications, pp. 177-181. Edited by L. Emoődy, T. Pál, J. Hacker \& G. Blum-Oehler. New York: Springer.

Kyte, J. \& Doolittle, R. F. (1982). A simple method for displaying the hydropathic character of a protein. J Mol Biol 157, 105-132.

Laemmli, U. K. (1970). Cleavage of structural proteins during the assembly of the head of bacteriophage T4. Nature 227, 680-685.

Lerner, A., Herschkovitz, Y., Baudoin, E., Nazaret, S., MoenneLoccoz, Y., Okon, Y. \& Jurkevitch, E. (2006). Effect of Azospirillum brasilense inoculation on rhizobacterial communities analyzed by denaturing gradient gel electrophoresis and automated ribosomal intergenic spacer analysis. Soil Biol Biochem 38, 1212-1218.

Lüderitz, O., Freudenberg, M. A., Galanos, C., Lehmann, V., Rietschel, E. Th. \& Shaw, D. H. (1982). Lipopolysaccharides of Gram-negative bacteria. Curr Top Membr Transp 17, 79-151.

Mao, Y., Doyle, M. P. \& Chen, J. (2001). Insertion mutagenesis of wca reduces acid and heat tolerance of enterohemorrhagic Escherichia coli O157 : H7. J Bacteriol 183, 3811-3815.

Matora, L. Y., Solovova, G. K., Serebrennikova, O. B., Selivanov, N. Y. \& Shchyogolev, S. Y. (1995). Immunological properties of Azospirillum cell surface: the structure of carbohydrate antigens and evaluation of their involvement in bacteria-plant contact interactions. In Azospirillum VI and Related Microorganisms, pp. 377-382. Edited by I. Fendrik, M. del Gallo, M. de Zamaroczy \& J. Vanderleyden. Berlin: Springer.

McKay, G. A., Woods, D. E., MacDonald, K. L. \& Poole, K. (2003). Role of phosphoglucomutase of Stenotrophomonas maltophilia in lipopolysaccharide biosynthesis, virulence, and antibiotic resistance. Infect Immun 71, 3068-3075.

Michel, G., Ball, G., Goldberg, J. B. \& Lazdunski, A. (2000). Alteration of the lipopolysaccharide structure affects the functioning of the Xcp secretory system in Pseudomonas aeruginosa. J Bacteriol 182, 696703.

Michiels, K. W., Croes, C. L. \& Vanderleyden, J. (1991). Two different modes of attachment of Azospirillum brasilense Sp7 to wheat roots. J Gen Microbiol 137, 2241-2246.

Moens, S. \& Vanderleyden, J. (1996). Functions of bacterial flagella. Crit Rev Microbiol 22, 67-100.

Moniot-Ville, N., Guibert, J., Acar, J. F., Collatz, E. \& Gutmann, L. (1991). Mechanisms of quinolone resistance in a clinical isolate of Escherichia coli highly resistant to fluoroquinolones but susceptible to nalidixic acid. Antimicrob Agents Chemother 35, 519-523.

Nikaido, H. \& Vaara, M. (1985). Molecular basis of bacterial outer membrane permeability. Microbiol Rev 49, 1-32.

Nurminen, M., Hirvas, L. \& Vaara, M. (1997). The outer membrane of lipid A-deficient Escherichia coli mutant LH530 has reduced levels of OmpF and leaks periplasmic enzymes. Microbiology 143, 1533-1537.

Ophir, T. \& Gutnick, D. L. (1994). A role for exopolysaccharides in the protection of microorganisms from desiccation. Appl Environ Microbiol 60, 740-745.

Pattanaik, B., Schumann, R. \& Karsten, U. (2007). Effects of ultraviolet radiation on cyanobacteria and their protective mechanisms. In Algae and Cyanobacteria in Extreme Environments, pp. 31-48. Edited by J. Seckbach. Dordrecht, The Netherlands: Springer.

Petrova, L. P., Matora, L. Y., Burygin, G. L., Borisov, I. V. \& Fatsy, E. I. (2005). Analysis of DNA, lipopolysaccharide structure, and some cultural and morphological properties in closely related strains of Azospirillum brasilense. Mikrobiologiia 74, 224-230 (in Russian).

Puente, M. E., Holguin, G., Glick, B. R. \& Bashan, Y. (1999). Rootsurface colonization of black mangrove seedlings by Azospirillum halopraeferens and Azospirillum brasilense in seawater. FEMS Microbiol Ecol 29, 283-292. 
Rahaman, S. O., Mukherjee, J., Chakrabarti, A. \& Pal, S. (1998). Decreased membrane permeability in a polymyxin B-resistant Escherichia coli mutant exhibiting multiple resistance to $\beta$-lactams as well as aminoglycosides. FEMS Microbiol Lett 161, 249-254.

Rajyaguru, J. M. \& Muszynski, M. J. (1997). Association of resistance to trimethoprim/sulphamethoxazole, chloramphenicol and quinolones with changes in major outer membrane proteins and lipopolysaccharide in Burkholderia cepacia. J Antimicrob Chemother 40, 803-809.

Reizer, J., Reizer, A. \& Saier, M. H., Jr (1992). A new subfamily of bacterial ABC-type transport systems catalyzing export of drugs and carbohydrates. Protein Sci 1, 1326-1332.

Reuhs, B. L., Geller, D. P., Kim, J. S., Fox, J. E., Kolli, V. S. K. \& Pueppke, S. G. (1998). Sinorhizobium fredii and Sinorhizobium meliloti produce structurally conserved lipopolysaccharides and strain-specific K antigens. Appl Environ Microbiol 64, 4930-4938.

Riou, N., Poggi, M. C. \& Le Rudukier, D. (1991). Characterization of an osmoregulated periplasmic glycine betaine-binding protein in Azospirillum brasilense Sp7. Biochimie 73, 1187-1193.

Roberson, E. B. \& Firestone, M. K. (1992). Relationship between desiccation and exopolysaccharide production in a soil Pseudomonas sp. Appl Environ Microbiol 58, 1284-1291.

Rodríguez Cáceres, E. A. (1982). Improved medium for isolation of Azospirillum spp. Appl Environ Microbiol 44, 990-991.

Saigi, F., Climent, N., Piqué, N., Sanchez, C., Merino, S., Rubirés, X., Aguilar, A., Tomás, J. M. \& Regué, M. (1999). Genetic analysis of the Serratia marcescens N28b O4 antigen gene cluster. J Bacteriol 181, 1883-1891.

Sambrook, J., Fritsch, E. F. \& Maniatis, T. (1989). Molecular Cloning: a Laboratory Manual, 2nd edn. Cold Spring Harbor, NY: Cold Spring Harbor Laboratory.

Schneider, E. \& Hunke, S. (1998). ATP-binding-cassette (ABC) transport systems: functional and structural aspects of the ATPhydrolyzing subunits/domains. FEMS Microbiol Rev 22, 1-20.

Silver, R. P., Prior, K., Nsahlai, C. \& Wright, L. F. (2001). ABC transporters and the export of capsular polysaccharides from Gramnegative bacteria. Res Microbiol 152, 357-364.

Simon, R., Priefer, U. \& Puhler, A. (1983). A broad host range mobilization system for in vivo genetic engineering: transposon mutagenesis in Gram negative bacteria. Biotechnology 1, 784-791.

Steenhoudt, O. \& Vanderleyden, J. (2000). Azospirillum, a free-living nitrogen-fixing bacterium closely associated with grasses: genetic, biochemical and ecological aspects. FEMS Microbiol Rev 24, 487-506.

Sukupolvi, S. \& Vaara, M. (1989). Salmonella typhimurium and Escherichia coli mutants with increased outer membrane permeability to hydrophobic compounds. Biochim Biophys Acta 988, 377-387.

Tao, H., Brewin, N. J. \& Noel, K. D. (1992). Rhizobium leguminosarum CFN42 lipopolysaccharide antigenic changes induced by environmental conditions. J Bacteriol 174, 2222-2229.
Tarrand, J. J., Krieg, N. R. \& Dobereiner, J. (1978). A taxonomic study of the Spirillum lipoferum group with the description of a new genus, Azospirillum gen. nov. and two species, Azospirillum lipoferum (Beijerinck) comb. nov. and Azospirillum brasilense sp. nov. Can J Microbiol 24, 967-980.

Thomsen, L. E., Chadfield, M. S., Bispham, J., Wallis, T. S., Olsen, J. E. \& Ingmer, H. (2003). Reduced amounts of LPS affect both stress tolerance and virulence of Salmonella enterica serovar Dublin. FEMS Microbiol Lett 228, 225-231.

Touze, T., Goude, R., Georgeault, S., Blanco, C. \& Bonnassie, S. (2004). Erwinia chrysanthemi $\mathrm{O}$ antigen is required for betaine osmoprotection in high-salt media. J Bacteriol 186, 5547-5550.

Tsai, C. M. \& Frasch, C. E. (1982). A sensitive silver stain for detecting lipopolysaccharides in polyacrylamide gels. Anal Biochem 119, 115119.

Turcotte, M. L., Martin, D., Brodeur, B. R. \& Peppler, M. S. (1997). Tn5-induced lipopolysaccharide mutations in Bordetella pertussis that affect outer membrane function. Microbiology 143, 2381-2394.

Vanbleu, E., Marchal, K., Lambrecht, M., Mathys, J. \& Vanderleyden, J. (2004). Annotation of the pRhico plasmid of Azospirillum brasilense reveals its role in determining the outer surface composition. FEMS Microbiol Lett 232, 165-172.

Vanstockem, M., Michiels, K., Vanderleyden, J. \& Van Gool, A. P. (1987). Transposon mutagenesis of Azospirillum brasilense and Azospirillum lipoferum: physical analysis of Tn5 and Tn5-mob insertion mutants. Appl Environ Microbiol 53, 410-415.

Wai, S. N., Mizunoe, Y. \& Yoshida, S. I. (1999). How Vibrio cholerae survive during starvation. FEMS Microbiol Lett 180, 123-131.

Wang, H., Jiang, X., Mu, H., Liang, X. \& Guan, H. (2007). Structure and protective effect of exopolysaccharide from $P$. agglomerans strain KFS-9 against UV radiation. Microbiol Res 162, 124-129.

Whitfield, C., Keenleyside, W. J. \& Clarke, B. R. (1994). Structure, function and synthesis of cell surface polysaccharides in Escherichia coli. In Escherichia coli in Domestic Animals and Man, pp. 437-494. Edited by C. L. Gyles. Wallingford, UK: CAB International.

Wolf, J. K. \& Goldberg, J. B. (2006). Bacterial cell walls. In Molecular Paradigms of Infectious Disease, pp. 176-206. Edited by C. A. Nickerson \& M. J. Schurr. New York: Springer.

Yokota, S. \& Fujii, N. (2007). Contributions of the lipopolysaccharide outer core oligosaccharide region on the cell surface properties of Pseudomonas aeruginosa. Comp Immunol Microbiol Infect Dis 30, 97109.

Zuleta, L. F. G., Italiani, V. C. S. \& Marques, M. V. (2003). Isolation and characterization of $\mathrm{NaCl}$-sensitive mutants of Caulobacter crescentus. Appl Environ Microbiol 69, 3029-3035.

Edited by: Michael F. Hynes 